\title{
Anti-inflammatory cytokines (IL-4, IL-10, IL-13) in plasma during mesenteric infarction
}

\author{
N. Nathan ${ }^{1, C A}$ and Y. Denizot ${ }^{2}$
}

${ }^{1}$ Department d'Anesthesie-Réanimation, $\mathrm{CHU}$

Dupuytren, 2 Avenue Martin Luther King, 87042

Limoges, and ${ }^{2}$ Laboratoire d'Hématologie

Expérimentale, Faculté de Médecine, 2 rue Dr.

Marcland, 87025 Limoges, France

${ }^{\mathrm{CA}}$ Corresponding Author
Fax: (+ 33) 0555056792

We have recently reported that excessive synthesis of proinflammatory cytokines such as interleukin-6 (IL6) and IL-8 may play a role in the pathogenesis of mesenteric infarction. ${ }^{1}$ IL 4 , IL-10 and IL-13 are classified as anti-inflammatory cytokines because they reduce the secretion of proinflammatory cytokines by stimulated monocytes/macrophage.$^{2-4}$ During several inflammatory states anti-inflammatory cytokines are elevated suggesting their putative regulatory role in limiting the duration and extent of the acute inflammatory response. ${ }^{5,6}$ We have investigated (using ELISA kits from TEBU, France) the concentration of IL-4, IL10 and IL-13 in the plasma of three patients with a mesenteric infarction before multiple organ failure development and in 10 atherosclerotic patients. Plasma IL-10 levels were significantly $(P=0.0001$, Mann-Whitney $U$-test) higher in patients with mesenteric infarct $(93.5 \pm 71.9 \mathrm{pg} / \mathrm{ml})$ than in atherosclerotic patients $(3.2 \pm 0.6 \mathrm{pg} / \mathrm{ml})$. In contrast, IL 4 and IL-13 were not detected in the plasma of mesenteric infarct and atherosclerotic patients.

As for other cytokines detected in higher circulating levels during mesenteric infarct, ${ }^{1}$ IL-10 also represents a marker of the exacerbation of the cytokine production in these patients. The clinical usefulness of these elevated IL-10 plasma concentrations requires further evaluation. It might be suggested that they could reflect an attempt by the organism to decrease the circulating proinflammatory cytokine activity. Despite similar activities between IL-4, IL-10 and IL-13 on the synthesis of inflammatory cytokines by activated mononuclear cells, ${ }^{2-4}$ we found that IL 4 and IL-13 are not elevated in plasma during mesenteric infarct indicating that the production of the various anti-inflammatory cytokines are differently regulated in these patients.

\section{References}

1. Nathan N, Denizot Y, Feiss P. Eicosanoid and cytokine levels in plasma of patients during mesenteric infarction. Med Inflamm 1997; 6: 75-77.

2. Wang P, Wu P, Siegel MI, Egan RW, Billah MM. IL-10 inhibits transcription of cytokine genes in human peripheral blood mononuclear cells. $J$ Immunol 1994; 153: 811-816.

3. de Wall Malefyt R, Figdor CG, Huijbens R, Mohan-Peterson S, Bennett B, Culpepper J, Dang W, Zurawski G, de Vries JE. Effects of IL-13 on phenotype, cytokine production, and cytotoxic function of human monocytes. Comparison with IL 4 and modulation by IFN- $\gamma$ or IL-10. J Immunol 1993; 151: 6370-6381.

4. Takeshita S, Gage JR, Kishimoto T, Vredevoe DL, Martinez-Maza O. Differential regulation of IL- 6 gene transcription and expression by IL 4 and IL-10 in human monocytic cell lines. J Immunol 1996; 156: 2591-2598.

5. van der Poll T, de Waal Malefyt R, Coyle SM, Lowry SF. Antiinflammatory cytokine responses during clinical sepsis and experimental endotoxemia: sequential measurements of plasma soluble interleukin (IL)-1 receptor type II, IL-10, and IL-13. I Infect Dis 1997; 175: 118-122.

6. Hasegawa M, Fujimoto M, Kikuchi K, Takehara K. Elevated serum levels of interleukin 4 (IL-4), IL-10, and IL-13 in patients with systemic sclerosis. J Rheumatol 1997; 24: 328-332.

Received 19 December 1997; accepted 9 January 1998 


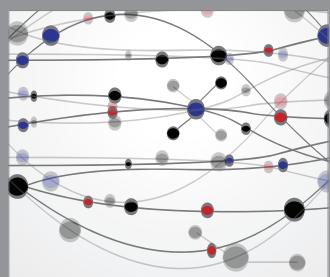

The Scientific World Journal
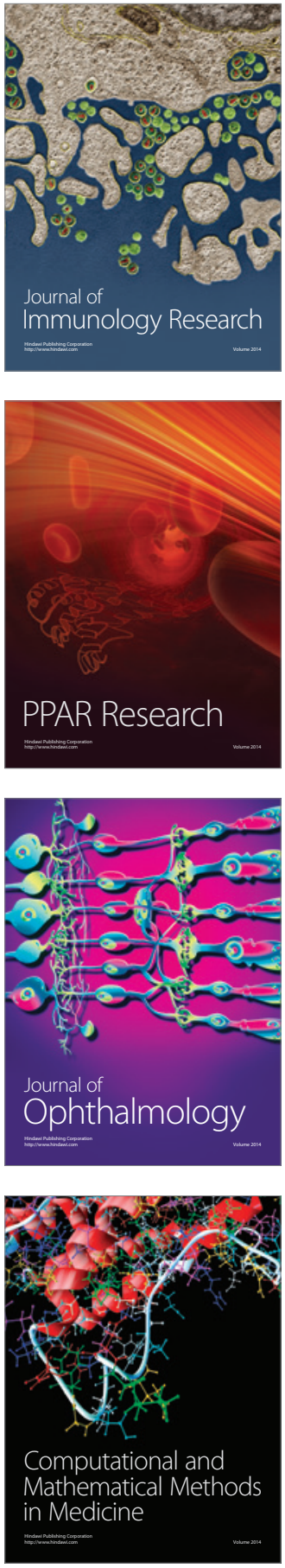

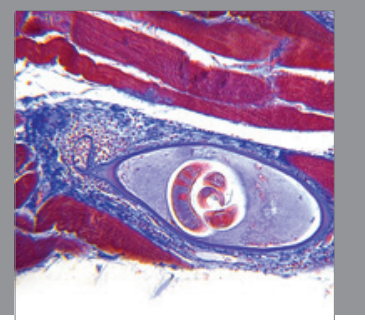

Gastroenterology

Research and Practice
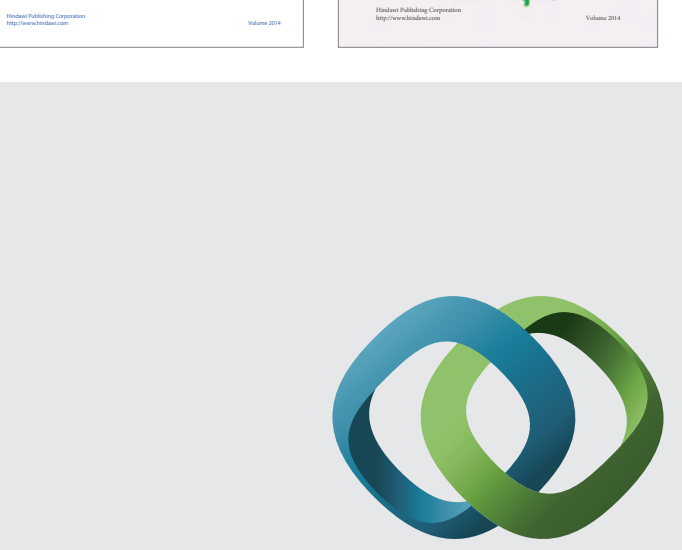

\section{Hindawi}

Submit your manuscripts at

http://www.hindawi.com
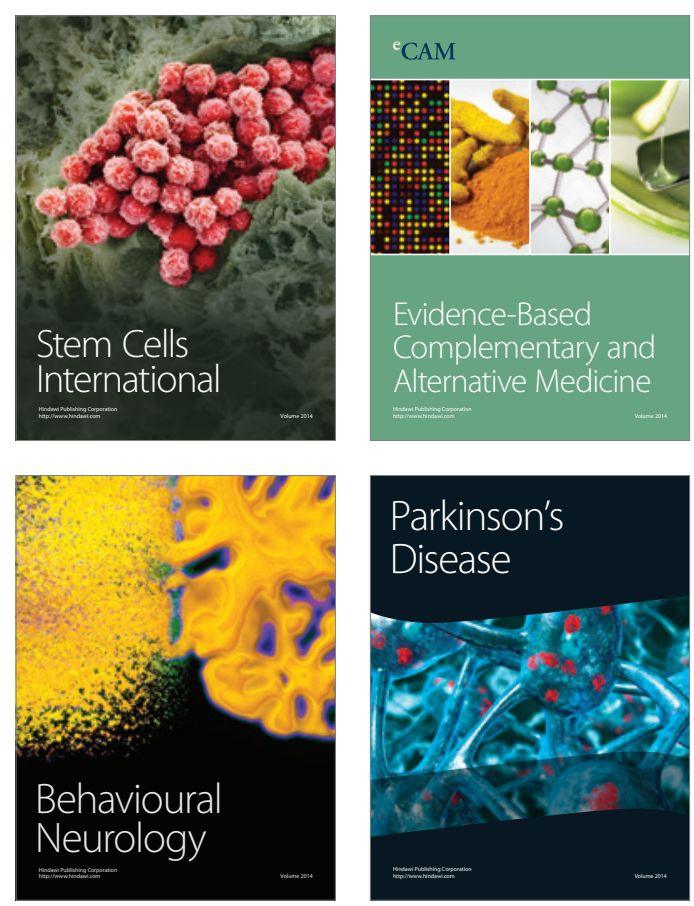

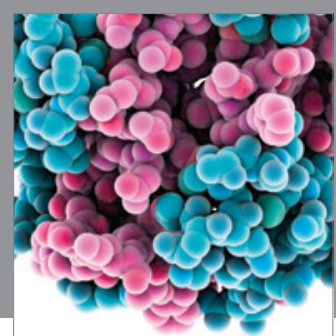

Journal of
Diabetes Research

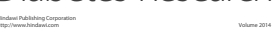

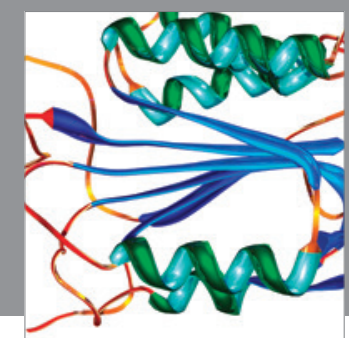

Disease Markers
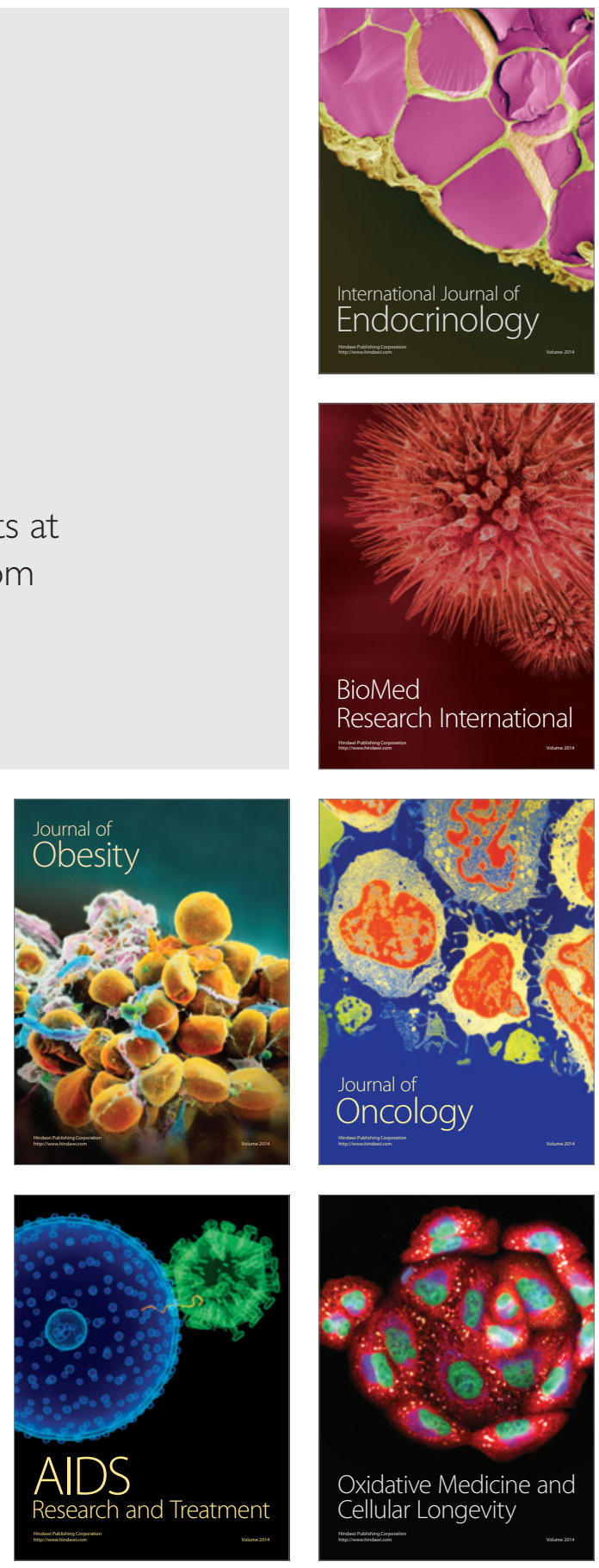